\title{
Pengaruh Strategi Pembelajaran Heuristic Vee Terhadap Pemahaman Konsep Matematis Peserta Didik
}

\author{
Riska Rahmawati ${ }^{*}$, Rubhan Masykur ${ }^{2}$, Abi Fadila² \\ ${ }^{1}$ bimbel prestasi Jalan Satria Sukabumi2 Bandar Lampung \\ ${ }^{2}$ Universitas Islam Negeri Raden Intan Lampung, Jalan Endro Suratmin, Sukarame, Bandar \\ Lampung 35133, Indonesia \\ *Corresponding Author. E-mail: riskarahmawati104@gmail.com
}

Received : 28-06-2018; Revised : 25-07-2018; Accepted : 27-07-2018

\begin{abstract}
Abstrak
Kemampuan pemahaman konsep matematis peserta didik itu penting. Akan tetapi beberapa penelitian yang telah ada menyatakan bahwa pemahaman konsep matematis peserta didik masih rendah. Rendahnya pemahaman konsep matematis peserta didik diduga disebabkan karena peserta didik masih kesulitan dalam menyelesaikan soal-soal matematika dan kurang aktif dalam proses pembelajaran dikelas. Penerapan strategi pembelajaran heuristic vee diharapkan bisa memperbaiki masalah tersebut. Tujuan dari penelitian ini adalah untuk mengetahui pengaruh strategi pembelajaran heuristic vee terhadap kemampuan pemahaman konsep matematis peserta didik. Jenis penelitian ini menggunakan penelitian Quasi Experiment Design dan Teknik sampling yang digunakan adalah metode Probability Sampling dengan tehnik Random Sampling. Uji hipotesis yang digunakan dalam penelitian ini yaitu uji-t. Hasil penelitian uji statistic menunjukkan bahwa nilai dari $t_{\text {hitung }}$ berdasarkan perhitungan yang diperoleh $t_{\text {hitung }}=2,096$, dan $t_{\text {tabel }}=1,998$ sehingga $t_{\text {hitung }}>t_{\text {tabel }}$, dengan taraf nyata 0,05 dengan kata lain dapat disimpulkan bahwa terdapat pengaruh yang signifikan penggunaan model heuristic vee terhadap kemampuan pemahaman konsep peserta didik. Selanjutnya pemahaman konsep matematis siswa yang diterarapkan strategi pembelajaran heuristic vee lebih baik dari kemampuan pemahaman konsep yang diterapkan dengan metode ceramah.
\end{abstract}

Kata Kunci :Heuristik vee, kemampuan pemahaman konsep matematis.

\begin{abstract}
The ability to understand the mathematical concepts of learners is important. However, some existing research suggests that understanding of the mathematical concepts of learners is still low. The low understanding of the mathematical concepts of learners is allegedly caused because students are still difficult in solving math problems and less active in the process of learning in class. The implementation of the heuristic vee expenditure strategy is expected to improve the problem. The purpose of this study is to determine the effect of heuristic vee learning strategy on the ability to understand the mathematical concepts of learners. This research type used QuasiExperiment Design research and sampling technique used is Probability Sampling method with Random Sampling technique. Hypothesis test used in this research is the t-test. The result of statistical test shows that the value of $t_{-}$hitung based on the calculation obtained t_hitung $=2.096$, and t_table $=1.998$ so $t_{-}$hitung $>$t_table, with a real level of 0.05, in other words, it can be concluded that the students' mathematical concept understanding that expected heuristic vee learning strategy better from the conceptual comprehension ability applied by the lecture method.
\end{abstract}

Keywords: Heuristic vee, ability to comprehend mathematical concepts

\section{PENDAHULUAN}

Kemampuan pemahaman konsep yang dicapai peserta didik tidak dapat dipisahkan dengan masalah pembelajaran yang merupakan alat ukur penguasaan materi yang diajarkan (Permata, Sutijan, 
\& WA, 2016). Namun kenyataannya kemampuan pemahanan konsep peserta didik masih belum menggembirakan. Kondisi ini didukung pernyataan yang diungkapkan oleh (Fristady, Noer, \& Djalil, 2014; Hardianti, Djalil, \& Coesamin, 2015) penelitian sebelumnya bahwa tingkat pemahaman konsep peserta didik masih sangat rendah. Tidak hanya peserta didik di sekolah, permasalahan kemampuan pemahaman konsep matematis juga terjadi pada mahasiswa seperti yang telah dijelaskan oleh (Sudarman \& Vahlia, 2016). Dikhawatirkan rendahnya kemampuan peserta didik dalam memahami konsep materi disebabkan karena strategi pembelajaran yang digunakan. Permasalahan ini disebabkan oleh strategi pembelajaran yang kurang tepat dalam pembelajaran yang kurang tepat dalam pembelajaran matematik (Netriwati, 2016; Purwasih, 2015; Yusri, 2016). Diduga strategi pembelajaran Heuristik vee mampu mengatasi permasalahan pada kemampuan pemahaman konsep matematis.

Berdasarkan uraian diatas dapat diketahui bahwa perlu ditingkatkan lagi kemampuan pemahaman konsep matematis peserta didik agar semua peserta didik mempunyai pemahaman yang baik akan materi yang sudah diajarkan dan tidak mudah melupakan rumus yang sudah diajarkan sebelumnya. Sehingga semua siswa akan dapat mengerjakan berbagai jenis soal baik dari yang mudah, sedang, maupun susah.

Dari hasil penelitian sebelumnya mengungkapkan bahwa srategi pembelajaran Heuristik vee mampu meningkatkan pemahaman konsep peserta didik (Netriwati, 2016; Purwasih, 2015). Selain itu penelitian lainnya menghasilkan bahwa pengaruh strategi Heuristik vee untuk memecahkan masalah dalam kemampuan pemahaman konsep peserta didik (Wardani, Yamtinah, \& Mulyani, 2015). Kemudian penelitian selanjutnya bahwa pengaruh strategi Heuristik vee hasil belajar peserta didik . sedangkan penelitian berikutnya mengungkapkan bahwa ada pengaruh model Heuristik vee dengan peta konsep terhadap kemampuan pemahaman konsep matematis peserta didik (Jayanti, Suarjana, \& Widiana, 2014)

Penelitian

mengungkapkan bahwa pengaruh strategi Heuristik vee terhadap pemecahan masalah matematis peserta didik (Zulfah, 2018). penelitian lainnya menjelaskan bahwa meningkatkan kemampuan pemahaman konsep matematis dengan menggunakan model pembelajaran Heuristik vee (Wahyuni, Yamtinah, \& Utami, 2015). kemudian penelitian berikutnya bahwa meningkatkan kemampuan pemahaman konsep peserta didik menggunakan strategi pembelajaran Heuristik vee (Farida, 2015). Berdasarkan pembahasan diatas dapat disimpulkan bahwa perbedaan penelitian ini dengan penelitian sebelumya yaitu dalam penelitian ini strategi pembelajaran Heuristik vee berpengaruh terhadap pemahaman konsep matematik peserta didik.

Berdasarkan penelitian sebelumnya yang telah dipaparkan, maka dalam penelitian ini, peneliti tertarik melakukan sebuah penelitian menggunakan strategi pembelajaran Heuristik vee pemahaman konsep matematik peserta didik untuk mengatasi permasalahan pemahaman konsep matematik peserta didik. Dalam penelitian ini pembelajaran Heuristik vee disinergikan dengan strategi pembelajaran lain atau dapat dikatakan pembelajaran Heuristik vee.

Peneliti ini akan berbeda dengan penelitian sebelumnya dimana pembelajaran Heuristik vee terhadap pemahaman konsep matematik peserta didik. Selain itu, pembelajaran Heuristik vee disinergikan dengan sebuah 
pemahaman konsep yang lain. Disini peneliti melakukan modifikasi pada langkah-langkah pembelajaran Heuristik vee yaitu dengan menambahkan langkahlangkah pembelajaran baru dalam pembelajaran Heuristik vee itu sendiri. Adapun langkah pembelajaran tersebut adalah peserta didik membuat sebuah kelompok dan mencari pengetahuan baru. Adapun tujuannya yaitu untuk melihat pengaruh pemahaman konsep matematik peserta didik dengan pembelajaran Heuristik vee lebih baik daripada kemampuan pemahaman konsep matematik dengan pembelajaran konvensional.

\section{METODE}

Metode penelitian yang digunakan pada penelitian ini adalah menggunakan penelitian eksperimen karena penulisakan mencari perbedaan treatment (perlakuan) tertentu. Dengan desain penelitian sebagai berikut :

Tabel 1. Desain Penelitian

\begin{tabular}{ccc}
\hline Kelompok & Perlakuan & Posttest \\
eksperimen & $x_{e}$ & $O_{2}$ \\
kontrol & $x_{k}$ & $O_{4}$ \\
\hline
\end{tabular}

Keterangan:

$x_{e}$ : kemampuan pemahaman konsep matematis peserta didik yang mendapat perlakuan Strategi Pembelajaran Heuristic Vee

$x_{k}$ : kemampuan pemahaman konsep matematis peserta didik yang mendapat perlakuan metode ceramah

$\mathrm{O}_{2}$ : Posttest

$\mathrm{O}_{4}$ : Posttest

Teknik pengambilan sample yang digunakan adalah purposive sampling. Teknik pengumpulan data yang digunakan adalah wawancara, tes, dokumentasi. Model tes digunakan untuk mengumpulkan data kemampuan pemahaman konsep peserta didik dengan tes berbentuk essay. Tes diberikan setelah memenuhi validitas soal dan diujicobakan terlebih dahulu di untuk melihat tingkat kesukaran dan daya pembeda butir soal tersebut, serta uji reliabilitas terhadap masing-masing instrumen tes.

Sebelum dilakukan uji hipotesis, terlebih dahulu dilakukan uji prasyarat analisis pada kemampuan awal siswa masing-masing kelas yang diambil dari tes kemampuan pemahaman konsep untuk uji keseimbangan dengan taraf signifikansi 0.05 . Teknik analisis data dalam pengujian hipotesis adalah sebagai berikut (Novalia \& Syazali, 2014):

1. Uji normalitas

Uji normalitas dengan menggunakan metode Lilifors, dengan rumus:

$L_{\text {hitung }}=\operatorname{Max}|f(z)-S(z)|, L_{\text {tabel }}=$ $L_{(\alpha, n)}$

Dengan hipotesis

$\mathrm{H}_{0}$ : data mengikuti sebaran normal

$\mathrm{H}_{1}$ : data tidak mengikuti sebaran

normal

Kriteria uji

Jika $L_{\text {hitung }} \leq$

$L_{\text {tabel }}$ maka $H_{0}$ diterima.

Dengan taraf signifikan $\alpha=0,05$

2. Uji Homogenitas

Uji homogenitas dengan menggunakan uji kesamaan 2 varians. rumus yang digunakan dalam mencari $\mathrm{F}_{\text {hitung : }}$

$F=\frac{\text { Varians Terbesar }}{\text { Varians Terkecil }}$

Kriteria uji,

jika $F_{\text {hitung }} \leq: F_{\text {tabel, }}$

maka $\mathrm{H}_{0}$ adalah Homogen

$H_{0}: \sigma_{1}=\sigma_{2}$, bahwa $H_{0}$ diterima atau sempel berasal dari populasi yang memiliki varians sama (Data homogen).

$H_{1}: \sigma_{1} \neq \sigma_{2}, \quad H_{1}$ ditolak atau sempel berasal dari populasi yang memiliki varians tidak sama (Data tidak homogen). 
Jika hasil uji berdistribusi normal dan berasal dari daerah varians yang sama maka dilakukan uji Hipotesis Statistik menggunakan uji-t. untuk hipotesis dari hasil uji t yang digunakan adalah sebagai berikut

$H_{0}: \mu_{1} \leq \mu_{2}$ (Rata-rata kemampuan

pemahaman konsep dengan menggunakan model pembelajaran hauristik vee kurang dari atau sama dengan rata-rata peningkatan penguasaan konsep dengan menggunakan model konvensional).

$H_{1}: \mu_{1}>\mu_{2} \quad$ (Rata-rata kemampuan pemahaman konsep dengan menggunakan model pembelajaran hauristik vee lebih dari rata-rata kemamuan pemahaman konsep dengan menggunakan model konvensional)

$$
\begin{aligned}
& t_{\text {hitung }} \\
& =\frac{\bar{x}_{1}-\bar{x}_{2}}{\frac{\left(n_{1}-1\right) s_{1}^{2}+\left(n_{2}-1\right) s_{2}^{2}}{n_{1}+n_{2}-2}\left(\frac{1}{n_{1}}+\frac{1}{n_{2}}\right)}
\end{aligned}
$$

$$
t_{\text {tabel }}=t(\alpha, n 1+n 2-2)
$$

Keterangan :

$\overline{x_{1}} \quad=$ rata-rata nilai kelas eksperimen

$\overline{x_{2}} \quad=$ rata-rata nilai kelas kontrol

$S_{1}^{2}=$ varians kelas eksperimen

$S_{2}^{2} \quad=$ varians kelas kontrol

$n_{1} \quad=$ banyaknya siswa kelas eksperimen

$n_{2} \quad=$ banyaknya siswa kelas kontrol Hipotesis Uji :

$H_{0}: \mu_{1} \leq \mu_{2}$

$H_{1}: \mu_{1}>\mu_{2}$

Kriteria pengujian adalah :

jika $\left|t_{\text {hitung }}\right| \leq t_{\text {tabel }}$ maka $\mathrm{H}_{0}$ diterima.

\section{HASIL DAN PEMBAHASAN}

Setelah data hasil belajar peserta didik terkumpul baik dari kedua kelas, baik kelas eksperimen (Perlakuan metode heuristic vee) maupun dari kelas kontrol (Perlakuan metode ceramah) diperoleh maka diperoleh :

Tabel 1.Deskripsi Data tes kemampuan pemahaman konsep peserta didik

\begin{tabular}{lccccccc}
\hline \multicolumn{1}{c}{ Kelas } & $\mathbf{X}_{\text {maks }}$ & $\mathbf{X}_{\text {min }}$ & \multicolumn{3}{c}{ Ukuran Tendensi sentral } & \multicolumn{2}{c}{ Ukuran variansi kelompok } \\
& & & $\overline{\boldsymbol{x}}$ & $\mathbf{M e}$ & $\mathbf{M o}$ & $\mathbf{R}$ & Sd \\
Eksperimen & 100 & 65 & 83,4 & 80 & 82,5 & 35 & 10,5 \\
Kontrol & 100 & 50 & 70,6 & 65 & 70 & 50 & 13,6 \\
\hline
\end{tabular}

Setelah dilaksanakan pembelajaran, pada kelas eksperimen (Perlakuan metode heuristic vee) maupun dari kelas kontro (Perlakuan metode ceramah) dilakukan evaluasi akhir untuk mengetahui hasil belajar peserta didik sebagai pengumpulan data hasil evaluasi akhir diperoleh nilai tertinggi pada kelas eksperimen yaitu sebesar 100 dan kelas kontrol yaitu sebesar 100, sedangkan nilai terendah untuk kelas eksperimen adalah 65 dan kelas kontrol adalah 50 . Ukuran tendensi sentral yang meliputi rata-rata kelas (mean) untuk kelas eksperimen sebesar 83,4 dan kelas kontrol sebesar 70,6, sementara untuk nilai tengah kelas kelas eksperimen yaitu sebesar 80 dan kelas kontrol yaitu sebesar 65, sedangkan median dikelas eksperimen adalah 82,5 dan kelas kontrol adalah 70. Ukuran variansi kelompok meliputi jangkauan atau rentang untuk kelas eksperimen adalah 35 dan kelas kontrol adalah 50. Simpangan baku kelas eksperimen sebesar 10,5 dan kelas kontrol 13,6. Berdasarkan hal ini dapat disimpulkan bahwa hasil belajar peserta didik kelas eksperimen (Perlakuan metode heuristic vee) lebih baik dari kelas kontrol (Perlakuan metode ceramah). 
Selanjutnya dilakukan analisis uji asumsi dengan uji normalitas tes kemampuan pemahaman konsep peserta didik pada kelas eksperimen dengan hasil amatan dapat dilihat pada Tabel 2 .

\section{Tabel 2. Hasil uji normalitas kemampuan pemahaman konsep matematis peserta didik

\begin{tabular}{ccccccc}
\hline Kelas & $\overline{\boldsymbol{x}}$ & $\mathbf{S}$ & $\mathbf{A}$ & $\mathbf{L}_{\text {hitung }}$ & $\mathbf{L}_{\text {tabel }}$ & Keputusan Uji \\
Eksperimen & 83,4375 & 10,5828 & 0,05 & 0,1094 & 0,1542 & Normal \\
Kontrol & 71,5625 & 12,5362 & 0,05 & 0,1423 & 0,1542 & Normal \\
\hline
\end{tabular}

skor kelas eksperimen sebesar 81,4375 dengan $L_{\text {hitung }}=, 0,1094$ dan $L_{\text {tabel }}=0,1542$ hal ini menunjukan bahwa $L_{\text {hitung }}<L_{\text {tabel }}$ sehingga dapat disimpulkan data berdistribusi normal. Sedangkan kelas kontrol memperoleh sebesar 71,5625 dengan $L_{\text {hitung }}=$ 0,1423 dan $\quad L_{\text {tabel }}=0,1542$ hal ini menunjukan bahwa $L_{\text {hitung }}<L_{\text {tabel }}$ sehingga dapat disimpulkan data berdistribusi normal. Berikut hasil rekapitulasi perhitungan hasil belajar peserta didik pada kelas eksperimen dan kelas control Berdasarkan perhitungan hasil uji coba normalitas hasil belajar matematika peserta didik Kemampuan pada kelas eksperimen dan kelas kontrol dengan taraf sigifikansi $\alpha=0,05$, diperoleh bahwa nilai dari $L_{\text {hitung }}$ dari setiap kelompok kurang dari $L_{\text {tabel }}$ sehingga hipotesis nol dari setiap kelompok diterima. Dapat disimpulkan bahwa data yang diperoleh dari setiap kelompok berasal dari populasi yang berdistribusi normal.

Untuk mengetahui apakah kedua skor memiliki karakter yang sama atau berbeda maka diperlukan uji F. Pengujian variansi ini yaitu membandingkan varians terbesar dan varians terkecil. Jika $F_{\text {hitung }} \leq F_{\text {tabel }}\left(\sigma_{1}, \sigma_{2}\right) \quad$ didapat dari distribusi dengan peluang $\frac{1}{2} \alpha$ sedangkan derajat kebebasan $\sigma_{1}\left(n_{1}-1\right)$ dan $\sigma_{2}\left(n_{2}-2\right)$ masing-masing sesuai dengan $d k$ pembilang dan $d k$ penyebut. Hasil pengujian varians dengan taraf signifikan $\alpha=0,05$ dapat dilihat pada Tabel 3 .

Tabel 3. Hasil Perhitungan Uji Kesamaan Dua Varians

\begin{tabular}{ccccc}
\hline Kelas & Jumlah Sempel & $F_{\text {hitung }}\left(L_{(\alpha, n)}\right)$ & $\boldsymbol{F}_{\text {tabel }}$ & Keterangan \\
Eksperimen & 33 & 1,666 & 18,2213 & Homogen \\
kontrol & 33 & & & \\
\hline
\end{tabular}

Berdasarkan Tabel 3. Hasil perhitungan skor Kemampuan Pemahaman konsep matematis diperoleh $F_{\text {hitung }}=18,2213$ dan $F_{\text {tabel }}=1,666$. Menunjukan bahwa $F_{\text {hitung }}<F_{\text {tabel }}$ dengan hal ini dapat disimpulkan bahwa $H_{0}$ diterima atau sampel berasal dari populasi yang memiliki varians sama. Untuk menguji perbedaan hasil belajar matematis peserta didik digunakan rumus uji-t, karena data yang diperoleh berdistribusi normal dan memiliki nilai varians sama. Hasil perhitungan dapat dilihat pada Tabel 4. Berikut ini :

Tabel 4.HasilPerhitunganUji-t

\begin{tabular}{cccccc}
\hline Kelas & JumlahSempel & Rata-Rata $(\boldsymbol{x})$ & $\boldsymbol{t}_{\boldsymbol{t a b e l}}\left(\boldsymbol{t}_{\boldsymbol{a}, \boldsymbol{d} \boldsymbol{b}}\right)$ & $\boldsymbol{t}_{\text {hitung }}$ & Keterangan \\
Eksperimen & 33 & 83,4375 & \multirow{2}{*}{1,998} & 2,096 & \multirow{2}{*}{ Terima $\mathrm{H}_{0}$} \\
$\quad$ Kontrol & 33 & 71,5625 & & & \\
\hline
\end{tabular}


Berdasarkan Tabel 4. Perhitungan diperoleh $\quad \boldsymbol{t}_{\text {hitung }}=2,096 \quad$ dan $t_{\text {tabel }}=1,998$ sehingga $t_{\text {hitung }}>t_{\text {tabel }}$, yang berarti $\mathrm{H}_{0}$ ditolak. Dilihat dari ratarata hasil belajar peserta didik dapat dilihat pada table 4. Diperoleh kelas eksperimen (kelas yang mendapat perlakuan heuristic vee) memperoleh nilai 83,4375 yang sedangkan kelas kontrol (kelas yang mendapat perlakuan model ceramah) memperoleh nilai 71,5625 Dengan hasil analisis ini dapat disimpulkan bahwa ada perbedaanya itu kemampuan pemahaman konsep peserta didik peserta didik antara kelas eksperimen (kelas yang mendapat perlakuan heuristic vee) berpengaruh terhadap kemampuan pemahaman konsep peserta didik. Hal ini disebabkan karena pembelajaran Heuristik vee lebih banyak memberikan kesempatan peserta didik untuk belajar sendiri dan memecahkan masalah yang diberikan. Permasalahan tersebut dicari sebuah alternatif penyelesaiannya oleh mereka sendiri sehingga benar-benar paham materi. Selain itu, siswa membuat kelompok dan mencari pengetahuan baru yang diajarkan. dengan membentuk kelompok dan mencari pengetahuan baru dengan diagram $\mathrm{V}$ tersebut siswa lebih mudah memahami materi yang sudah diajarkan karena mereka sendiri yang membentuk kelompok dan mencari pengetahuan baru dengan menggunakan diagram $\mathrm{V}$ di buku mereka masingmasing.

Hasil penelitian ini menunjukkan bahwa peningkatan kemampuan pemahaman konsep matematis dengan pembelajaran Heuristik vee berpengaruh terhadap kemampuan pemahaman konsep dengan pembelajaran konvensional. Hal ini terbukti bahwa dalam penbelitian sebelumnya menjelaskan bahwa strategi pembelajaran Heuristik vee mampu meningkatkan pemahaman konsep peserta didik (Netriwati, 2016; Purwasih, 2015). Selain itu peneliti lainnya menghasilkan pengaruh strategi Heuristik vee untuk memecahkan masalah dalam kemampuan pemahaman konsep peserta didik (Wardani et al., 2015). sedangkan penelitian sebelumnya mengungkapkan bahwa pengaruh Heuristik vee pada peta konsep terhadap kemampuan pemahaman konsep matematis peserta didik (Jayanti et al., 2014).

Penelitian

mengungkapkan bahwa pengaruh strategi Heuristik vee terhadap kemampuan pemecahan masalah matematis peserta didik (Zulfah, 2018). penelitian lainnya menjelaskan bahwa meningkatkan kemampuan pemahaman konsep matematis dengan mengggunakan model pembelajaran Heuristik vee (Wahyuni et al., 2015). Kemudian penelitian berikutnya menjelaskan meningkatkan kemampuan pemahaman konsep dengan strategi pembelajaran Heuristik vee (Farida, 2015). Penelitian lainnya mengungkapkan bahwa meningkatkan pemahaman konsep peserta didik dengan menggunakan model pembelajaran quantum learning. Dari pembahasan diatas dapat disimpulkan bahwa hasil dari penelitian ini yaitu pengaruh pemahaman konsep matematik peserta didik dengan pembelajaran Heuristik vee lebih baik dibandingkan kemampuan pemahaman konsep matematik peserta didik dengan pembelajaran konvesional.

\section{SIMPULAN DAN SARAN}

Berdasarkan teori dan didukung oleh dengan hasil analisis dan pengolahan data serta mengacu pada perumusan masalah yang telah diuraikan, maka dapat disimpulkan bahwa: terdapat pengaruh kemampuan pemahaman konsep matematis peserta didik dengan penerapan model pembelajaran strategi pembelajaran heuristic vee. Selanjutnya 
kemampuan pemahaman konsep matematis peserta didik dengan strategi pembelajaranheuristic vee lebih baik dari pada model pembelajaran pembelajaran konvensional (ceramah).

Berdasarkan kesimpulan di atas maka penulis mamberikan saran sebagai berikut. Lembaga pendidikan khususnya dapat menerapkan strategi pembelajaran heuristic vee untuk melatih peserta didik ikut serta dalam proses pembelajaran dalam meningkatkan kemampuan pemahamankonsep matematis peserta didik. Harapan penulis yang lain adalah apa yang diteliti dapat memberikan manfaat dan sumbangan pemikiran bagi pendidik pada umumnya dan penulis pada khususnya.

\section{DAFTAR PUSTAKA}

Farida, F. (2015). Mengembangkan Kemampuan Pemahaman Konsep Peserta Didik Melalui Pembelajaran Berbasis VCD. Al-Jabar: Jurnal Pendidikan Matematika, 6(1), 25-32. https://doi.org/10.24042/ajpm.v6i1 .54

Fristady, R., Noer, S. H., \& Djalil, A. (2014). Efektivitas Model Pembelajaran Kooperatif Tipe TPS Terhadap Pemahaman Konsep Matematis Siswa. Jurnal Pendidikan Matematika Unila, 2(7).

Hardianti, D., Djalil, A., \& Coesamin, M. (2015). Efektivitas Model Pembelajaran Kooperatif Tipe NHT Ditinjau dari Pemahaman Konsep Matematis Siswa. Jurnal Pendidikan Matematika Unila, 3(2).

Jayanti, N. K., Suarjana, I. M., \& Widiana, I. W. (2014). Pengaruh Model Pembelajaran Heuristik-V Berbantuan Peta Konsep Terhadap Pemahaman Konsep IPA Siswa Kelas V. MIMBAR PGSD Undiksha, 2(1).

Netriwati, N. (2016). Analisis Kemampuan Mahasiswa dalam Pemecahkan Masalah Matematis menurut Teori Polya. Al-Jabar:
Jurnal Pendidikan Matematika, 7(2), 181-190.

https://doi.org/10.24042/ajpm.v7i2 .32

Novalia, N., \& Syazali, M. (2014). Olah Data Penelitian Pendidikan. Bandar Lampung: Anugrah Utama Rahaja.

Permata, S. D., Sutijan, M. I. S., \& WA, I. R. (2016). Penggunaan Model Pembelajaran ARIAS (Assurance, Relevance, Interest, Assessment, Satisfaction) Untuk Meningkatkan Penguasaan Konsep Perubahan Kenampakan Permukaan Bumi dan Benda Langit. Jurnal Didaktika Dwija Indria (SOLO), 4(8).

Purwasih, R. (2015). Peningkatan Kemampuan Pemahaman Matematis dan Self Confidence Siswa MTS di Kota Cimahi Melalui Model Pembelajaran Inkuiri Terbimbing. Didaktik, 9(1), 16-25.

Sudarman, S. W., \& Vahlia, I. (2016). Efektifitas Penggunaan Metode Pembelajaran Quantum Learning terhadap Kemampuan Pemahaman Konsep Matematis Mahasiswa. AlJabar : Jurnal Pendidikan Matematika, $7(2)$, 275-282. https://doi.org/10.24042/ajpm.v7i2 .42

Wahyuni, I. T., Yamtinah, S., \& Utami, B. (2015). Pengembangan Instrumen Pendeteksi Kesulitan Belajar Kimia Kelas X Menggunakan Model Testlet. Jurnal Pendidikan Kimia, 4(4), 222231.

Wardani, R. K., Yamtinah, S., \& Mulyani, B. (2015). Instrumen Penilaian Twotier Test Aspek Pengetahuan Untuk Mengukur Keterampilan Proses Sains (Kps) Pada Pembelajaran Kimia Untuk Siswa Sma/ma Kelas X. Jurnal Pendidikan Kimia, 4(4), 156162.

Yusri, R. (2016). Pengaruh Pendekatan Problem Centered Learning terhadap Kemampuan Pemahaman Konsep Matematis Siswa Kelas X SMA Negeri 
Desimal, 1 (3), 2018 - 264

Riska Rahmawati, Rubhan Masykur, Abi Fadila

Kabupaten Solok. PROSIDING, 2(1), 165-171.

Zulfah, Z. (2018). Pengaruh Penerapan Model Pembelajaran Kooperatif Tipe Think Pair Share Dengan Pendekatan Heuristik Terhadap Kemampuan

Pemecahan Masalah Matematis Siswa Mts Negeri Naumbai Kecamatan Kampar. Jurnal Cendekia: Jurnal Pendidikan Matematika,[SL], (2), 65-76. 